\title{
THE EFFECTS OF PHYSICS LEARNING WITH STARTER EXPERIMENT APPROACH (SEA) TO IMPROVE STUDENT LEARNING OUTCOMES
}

\author{
Faradiba 1), DediJuliasmanSakatsila2), ManogariSianturi3), Samuel Gideon ${ }^{4)}$ \\ 1,2,3Physics Education Program, Universitas Kristen Indonesia \\ Email: Ifaradiba@uki.ac.id
}

\begin{abstract}
According to regulation No. 20/2000, education is a conscious and planned effort to create an atmosphere of teaching and learning process. The students actively develop their potential to have spiritual strength, self-control, personality, intelligence, noble character, and the skills needed by themselves, society, nation, and country. To realize this, we need learning methods and models that can increase student enthusiasm and improve student learning outcomes. Of the several learning approaches, the initial experiment approach (starter experiment approach) is one alternative in learning physics-this research conducted from January to September 2018. The results showed that the average in class XI Natural Sciences at SMA Negeri 98 Jakarta, East Jakarta, and the posttest score of the experimental class students after receiving the SEA learning model treatment was 87.38 the class control with conventional learning models 80.36 .
\end{abstract}

Keywords: Physics learning, Starter Experiment Approach, Learning outcomes, Learning models, Learning methods, Student potential, Development potential.

\section{INTRODUCTION}

Education is the right of the whole nation. The primary purpose of education is to educate the nation; this is a state in the opening of the 1945 Constitution fourth paragraph. Besides, regulation No 20/2003 on the national education system which states: "education is a conscious and planned effort to create an atmosphere of learning and learning process so that students actively develop their potential to have religious, spiritual strength, selfcontrol, personality, intelligence, morals noble and the skills needed by himself, society, nation, and country."

In the realization of educational goals, as stated in the 1945 Constitution and regulation No. 20/2003, learning methods and models are needed that can increase student enthusiasm and, indeed, must be able to improve student learning outcomes. The success of teaching and learning activities must support teacher competence in the implementation of learning. The teacher is considered a profession when he has technical skills and supported by a healthy personality attitude. Thus, it means that professional teachers must have professional competence, personal or personality competence, social competence, and pedagogical competence. [1]

As a prospective professional teacher, researchers must be able to have the competencies mentioned above. It is the reason for the implementation of research activities at SMA Negeri 98 Jakarta. Based on observations at SMA Negeri 98 Jakarta, physics learning is still classified as monotonous, because the learning method is still conventional. It refers to the results of interviews with teachers and students. During the lesson, the teacher explains the material, provides examples of questions and exercises.

Even though the school has implemented the "2013 Curriculum," students should be required to be active and think critically in 
learning. It is due to the teacher's limited ability to implement the curriculum.

From the results of observations at the school, the average student's actual score has not yet reached the Minimum Completion Criteria (KKM), because the average student score reaches only 70 . At the same time, the KKM determined for class $\mathrm{XI}$ is 81 (based on new rules according to the 2013 curriculum). Based on an interview with one of the physics teachers of class XI Science at SMA Negeri 98 Jakarta, the low value of students due to lack of understanding of students with the material taught. However, because the demands of students 'scores must reach 81 according to the current curriculum, students are given assignments in the form of papers, clippings, and other writing assignments to improve students' grades. While for practicum activities are rarely done, because laboratory facilities do not support.

Besides, one of the physics teachers admitted that they had difficulty with this 2013 curriculum. Although this curriculum concept requires students to be active, and teachers must be able to design learning to be effective. It is difficult for the physics teachers at SMA Negeri 98 Jakarta to adjust to moving from the 2006 Education Unit Level Curriculum (KTSP) to the 2013 curriculum.

Based on interviews with students, physics lessons that have received are very monotonous. It positively affects the interest and value of students who classified as low. Some students also claimed that learning physics was challenging.

To improve learning outcomes, and motivation to learn students, especially the material Characteristics of Waves, teachers must prepare appropriate solutions by applying active and fun learning. From several learning approaches, researchers chose to use the initial experiment approach (starter experiment approach), as an alternative in learning physics. It hoped that through the Starter Experiment Approach (SEA), it could help learners' difficulties in learning and increase motivation and practice thinking, which will ultimately improve student learning outcomes. Besides that, through SEA, students can learn while playing, which expected to make the learning process more enjoyable.

The results of previous studies show that the calculation results obtained t-count $=3.698$ $>\mathrm{t}$-table $=2.045$, then $\mathrm{Ho}$ is rejected. So the learning outcomes of students on the subject matter of heat using the Starter Experiment Approach is effective compared to learning with conventional methods. In addition to improving student learning outcomes, learning using the initial experimental approach (Starter Experiment Approach) can also increase students' activeness in asking, explaining, and discussing to solve a problem. [2]

Another study with the title "Improvement of Physics Learning Outcomes Through Learning Starter Experiment Approach In Class VIII2 of SMP Negeri 2 Sungguminasa, Gowa" [3], the results of the research that achieved showed: (1) in the first cycle the average value of 68.81 with a standard deviation of 16.26. The percentage of student learning outcomes is $68.81 \%$; (2) in the second cycle; the average value is 72.86 with a standard deviation of 12.17. The percentage of student learning outcomes is $76.19 \%$. The results of the analysis showed that there was an increase in physics learning outcomes for students of class VIII-2 at SMP Negeri 2 Sungguminasa, Gowa, by $7.38 \%$ after the starter experiment learning approach (SEA) was applied and classically it had met the KKM. So that SEA learning can be used as an alternative in the physics learning process. 
Another study stated that Tarbiyah Faculty Students, Walisongo State Islamic Institute Semarang, with the title Effectiveness of Physics Science Learning with a Starter Experiment Approach in Heat Material on Learning Outcomes for Class VII Students of NU 09 Gemuh Academic Year $2011 / 2012$. Based on the study results, class VII B after learning heat material using conventional learning reached the highest value of 85 and the lowest value of 45 . The range of values $(R)=40$ and the length of the interval class took 7 , so the average value was 71.585 with standard deviation $=$ 9.66. [4]

Besides, a study entitled The Effectiveness of Starter Experiment Approach (SEA) against Students' High-Level Thinking Ability in Physics at Class XI of Science, State High School 1 Jatinom in the academic year $2014 / 2015$. The results showed learning using the Starter Experiment Approach (SEA) was effective on the ability to think of high levels of students in physics with moderate effects (sig (2-Tailed value) = 0.041 <sig.a 0.05; the percentage increase of students in the high category is $8 \%$, moderate is $38 \%$, and low is $54 \%$; $\mathrm{N}$-gain of the experimental class $=0.33>\mathrm{N}$-gain of the control class $=0.20$. [5]

\section{METHOD}

\section{Place and time of research}

Penelitian ini dilaksanakan di SMA Negeri 98 Jakarta, Jakarta Timur, dengan alokasi waktu penelitian mulai Januari hingga September 2018.

\section{Sample of research}

Populasi penelitian ini adalah seluruh siswa Kelas XI IPA SMA Negeri 98 Jakarta, yang terdiri dari 5 kelas. Sampel dalam penelitian adalah siswa kelas XI IPA 1 dan XI IPA 4. Kelas XI IPA 1 sebagai siswa kelas eksperimen yang mendapatkan pembelajaran dengan pendekatan percobaan awal (Starter experiment Approach). Sedangkan kelas XI IPA 4 sebagai siswa kelas kontrol yang mendapat pembelajaran dengan pendekatan konvensional.

Teknik pengambilan sampel dilakukan melalui Non- Probability Sampling / Non Random Sample dengan menggunakan metode Purposive Sampling.

\section{Design of research}

Desain penelitian ini menggunakan quasi experimental (eksperimen semu) dengan nonequivalent control group design. Hasilnya dianalisis secara statistik untuk mencari perbedaan variable yang diteliti.

\section{Data collection technique}

Teknik pengumpulan data yaitu proses diperolehnya data dari sumber data. Sumber data adalah subjek dari penelitian yang dimaksud untuk memperoleh datadata yang diinginkan. Dalam penelitian ini, teknik pengumpulan data yang digunakan adalah dokumentasi, tes, dan observasi.

\section{Instrument of research}

Instrumen yang digunakan dalam penelitian ini adalah tes kemampuan kognitif siswa. Instrumen yang digunakan adalah soal-soal yang disusun berdasarkan ranah kognitif yang menyangkut pengetahuan, pemahaman, penerapan, analisis, sintesis dan evaluasi sesuai dengan taksonomi bloom.

\section{Instrument Testing Techniques}

Instrumen penelitian sebelum diujikan harus diuji cobakan terlebih dahulu. Untuk mengetahui apakah instrumen itu baik, harus diketahui analisis validitas, reliabilitas, tingkat kesukaran soal dan daya pembeda soal.

\section{Data analysis technique}

Untuk mengetahui keakuratan data hasil penelitian, pada penelitian ini 
menggunakan pengujian data, antara lain: uji homogenitas data, uji normalitas data, uji hipotesis, uji N-gain.

\section{RESULTS}

\section{Results of Pretest AND Posttest Value}

\section{Result of Pretest}

Based on the data of students in grade XI MIPA 1 before being given SEA treatment, obtained the highest value of 60 and the lowest value of 25 . With a range of values of 35 . The length of the interval class taken 5 , the number of intervals taken 6. For grade XI MIPA 4 before learning with conventional approaches, the highest value is 60 , and the lowest value is 25 . With a range of values, 35 . The length of the interval class taken is 5 , and the number of intervals taken is 6 .

Table 1. List of Frequency Distribution of Pretest of Experiment Class and Control Class

\begin{tabular}{ccccc}
\hline $\begin{array}{c}\text { Interval } \\
\text { Class }\end{array}$ & $\begin{array}{c}\text { Absolute } \\
\text { Frequency } \\
\text { (Experiment) }\end{array}$ & Avg & $\begin{array}{c}\text { Absolute } \\
\text { Frequency } \\
\text { (Control) }\end{array}$ & Avg \\
\hline $25-30$ & 8 & & 1 & \\
$31-36$ & 4 & & 4 & \\
$37-42$ & 3 & & 3 & 50,70 \\
$43-48$ & 6 & 43,75 & 5 & \\
$49-54$ & 5 & & 3 & \\
$55-60$ & 10 & & 20 \\
\cline { 1 - 2 } Total & 36 & & 36 \\
\cline { 1 - 2 } & & &
\end{tabular}

\section{Result of Posttest}

Based on the results of the study, the grade $\mathrm{XI}$ MIPA 1 students after being given SEA treatment, the highest value 100, and the lowest value 81. Whereas for the XI MIPA 4 students, after learning with conventional methods, the highest value is 90 , and the lowest value is 65 . Following list of frequency distributions of the experimental class final values and the control class.
Table 2. List of Frequency Distribution Final Value of Experiment Class and Control Class

\begin{tabular}{ccccc}
\hline $\begin{array}{c}\text { Interval } \\
\text { Class }\end{array}$ & $\begin{array}{c}\text { Absolute } \\
\text { Frequency } \\
\text { (Experiment) }\end{array}$ & Avg & $\begin{array}{c}\text { Absolute } \\
\text { Frequency } \\
\text { (Control) }\end{array}$ & Avg \\
\hline $65-70$ & - & & 5 & \\
$71-76$ & - & & 6 & \\
$77-82$ & 4 & 87,3 & 9 & 80,3 \\
$83-88$ & 19 & 8 & 12 & 6 \\
$89-94$ & 7 & & 4 & \\
$95-100$ & 6 & & - & \\
\cline { 1 - 2 } Total & 36 & & 36 \\
\cline { 1 - 2 } & & & \multicolumn{2}{c}{} \\
\cline { 1 - 2 }
\end{tabular}

\section{Test of Data Homogeneity}

They tested the homogeneity of data analysis using the pretest value of the experimental class and the control class. Tests carried out using SPSS 21 for windows with Levene Statistics testing. The homogeneity test results of the pretest values shown in table 3 below.

Table 3. Homogeneity Analysis Test Data of Homogeneity of Variance of Pretest Values

\begin{tabular}{cccc}
\hline $\begin{array}{c}\text { Levene } \\
\text { Statistic }\end{array}$ & df1 & df2 & Sig. \\
\hline 1,614 & 1 & 70 &, 208 \\
\hline
\end{tabular}

Based on the homogeneity analysis of the pretest value of the experimental class and the control class, the significance level is $>0.05$, which is 0.208 . Thus, the data categorized as homogeneous.

\section{Test of Data Normality}

Data normality testing is doing to test the normality of the pretest value data. The following results of the data normality test for each class presented in table 4. 
Table 4. Results of Analysis of Normality of Tests of Normality Data

\begin{tabular}{ccccc}
\hline \multirow{2}{*}{$\begin{array}{c}\text { Descripti } \\
\text { on }\end{array}$} & \multirow{2}{*}{ Class } & \multicolumn{3}{c}{ Shapiro-Wilk } \\
\cline { 3 - 5 } & & Statistic & df & Sig. \\
\hline \multirow{2}{*}{ Pretest } & Experiment &, 918 & 36 &, 011 \\
& Control &, 852 & 36 &, 000 \\
\hline
\end{tabular}

\section{a. Lilliefors Significance Correction}

Based on the normality test table, the pretest value of the experimental class and the control class, sig. $<0.05$ which is 0.011 and 0.00 . Thus, student pretest value data is not normally distributing. The main cause of data not normally distributed is too extreme. That is because there is a pretest value data that does not balance with the average value of the entire sample.

\section{Test of Hypothesis}

Hypothesis testing using student post-test score data with SPSS 21 for window application. Hypothesis testing is done through non-parametric 2-Independent Sample statistical tests because the pretest value data is not a normal distribution, as shown in table 4. Testing criteria, if the Asymp value. Sig. (2-tailed)> 0.05 means there is no difference in learning with the SEA model, or in other words, $\mathrm{Ho}$ is accepted, and if the value of sig. (2-tailed) $<0.05$ means there is a difference, or $\mathrm{Ha}$ is accepted. Based on the results of the Statist Test output, as shown in Table 6, the Asymp value. Sig. (2-tailed) $<0.05$, which is 0,000 , then $\mathrm{Ha}$ is accepted. Thus it can be concluded that there is an influence of physics learning with an initial experiment approach (starter experiment approach) to improve student learning outcomes.

\section{Gain Test}

Based on the results of data analysis, the increase in student scores before and after the administration of treatment through the N-Gain test can see in table 5. N-Gain testing is carried out through the help of
Microsoft Excel to see in detail the increase in the value of each sample. In general, the n-gain test results with the help of Microsoft Excel show the value of the experimental class in the high category and the control category of the moderate category.

Table 5. Result of N-Gain Test

\begin{tabular}{cccc}
\hline \multicolumn{2}{c}{ Experiment Class } & \multicolumn{2}{c}{ Control Class } \\
\hline Category & Total & Category & Total \\
\hline Low & - & Low & 1 \\
Moderate & 8 & Moderate & 25 \\
High & 28 & High & 10 \\
\hline
\end{tabular}

Based on table 5, the N-Gain test results for the experimental class with a total sample of 36 experienced an increase in the high category of 28 samples and the moderate category of 8 samples. Meanwhile, an increase in student scores from the results of the n-gain test for the control class, 10 samples categorized as having a high increase in scores, 25 samples stated in the moderate value category, and 1 sample stated in the low-value category.

Table 6. Non-Parametric Test Results of Experiment Class and Control Class

\begin{tabular}{|c|c|}
\hline \multicolumn{2}{|c|}{ Test Statistics } \\
\hline & $\begin{array}{l}\text { Value of } \\
\text { Postest }\end{array}$ \\
\hline Mann-Whitney U & 291,500 \\
\hline Wilcoxon W & 957,500 \\
\hline Z & $-4,176$ \\
\hline Asymp. Sig. (2-tailed) &, 000 \\
\hline $\begin{array}{l}\text { a. Grouping Variable } \\
\text { Kelas }\end{array}$ & \\
\hline
\end{tabular}

\section{DISCUSSION}

This study aims to determine the effect of learning with the SEA model in improving student learning outcomes. To achieve these objectives, researchers analyzed student learning outcomes obtained from research activities through pretest and post-test. This research carried out at SMA Negeri 98 Jakarta. Based on the sampling 
technique with the purpose of sampling, the researcher determines class XI IPA 1 as an experimental class and class XI IPA 4 as a control class. Based on the results of the study, the pretest value of each class is almost the same. The lowest value is 25 , and the highest value is 60 . As for the posttest value, the lowest value for the experimental class is 81 , and the highest value is 100 . While for the lowest value is the control class 65 , and the highest value is 90 .

\section{CONCLUSION}

1. The results showed that the average post-test value of the experimental class students after receiving treatment of the SEA learning model was 87.38 , while the control class with the conventional learning model was 80.36 .

2. The average grade of experimental class students has met the Minimum Mastery Criteria (KKM), which is 81.00 , while the average value of control class students is still below the KKM.

3. Test results show that the Asymp value. Sig. (2-tailed) $0.00<0.05$, which means that there is an influence of physics learning with an initial experiment approach (starter experiment approach), in improving student learning outcomes in the material wave characteristics in class XI IPA 98 SMA Negeri Jakarta.

\section{REFERENCES}

Djam'an Satori, dkk. (2008). Profesi Keguruan. Jakarta: (Departemen Pendidikan Nasional, Ed.)

Endah Susilowati.(2010). "Pengaruh Pembelajaran Fisika dengan pendekatan percobaan awal (Starter Experiment Approach) pada pokok bahasan alat optik terhadap hasil pembelajaran fisika.Semarang : FMIPA Semarang.
Muhammad Cakra Jaya (2012). Peningkatan Hasil Belajar Fisika Melalui Pembelajaran Starter Experiment Approach Di Kelas VIII2 SMP Negeri 2 Sungguminasa Kab. Gowa. Makassar : Jurnal Pendidikan Fisika.Vol.2.

Siti Alimatul Farizal. (2011). Efektivitas Pembelajaran IPA Fisika Dengan Pendekatan Percobaan Awal (Starter Experiment Approach) Pada Materi Pokok Kalor Terhadap Hasil Belajar Peserta Didik Kelas VII MTS NU 09 Gemuh Tahun Pelajaran $2011 / 2012$.

Joko Purwanto, dkk.(2015). Efektivitas Starter Experiment Approach (SEA) Terhadap Kemampuan Berpikir Tingkat Tinggi Peserta Didik pada Pelajaran Fisika. Yogyakarta : UIN Sunan Kalijaga. 